\title{
TRACER STUDY OF 2009 -2011 PNU BSE-PE MAJOR GRADUATES
}

\author{
Rosanna A Diana \\ Philippine Normal University \\ rosannaadiana@gmail.com
}

\begin{abstract}
The Philippine Normal University (PNU), as the National Center for Teacher Education (NCTE), considers the evaluation of the impact of Teacher Education on students as one of its research priorities. Given the above-mentioned research priority of the University, this study was intended to determine if the curricular programs are being implemented appropriately at the classroom level and if there are desired effects on student achievement and employability. Further, this study looked into the some judgments about what aspects of the curriculum will be retained, enhanced or written off can be pursued if there is an evaluation process undertaken on which decisions will be based. Moreover, the experiences of those people involved in the implementation of the program will probably suffice which modifications and adjustments are appropriate. Results of the evaluation are expected to provide bases for further improving the curriculum and the success of the implementation process. This research used the following data gathering tools / procedure: ) Questionnaire developed by CHED specifically for Tracer Study research. The rating scale intended to determine the adequacy and relevance of the different course competencies of the program was included in the questionnaire. 2.) Focus Group Discussions were conducted. The scale items were consisted of program competencies resulting from the review of the course syllabi. The Tracer Survey Questionnaire was made available to the respondents through the web. The researcher tracked down and set up a directory of the graduates covered by the study. This study revealed that the Physical Education Curricular Program of the graduates BSE Physical Education of the College of Arts and Social Sciences from 2009 to 2011 is very adequate. The knowledge and skills developed during the Pre-service training are extremely relevant and useful to the performance of the tasks in their current employment.
\end{abstract}

Keywords: Tracer Study, Curricular Program, Evaluation, Skills and Competencies

As mandated, all Teacher Education Institutions (TEIs) are required to maintain a balance of advocacy and commitment to the trilogy of accountabilities on teaching, research and extension. The Philippine Normal University (PNU), as the National Center for Teacher Education (NCTE), shows its accountability to its stakeholders by providing key points to consider in revising and improving the programs it offers. 
The Department of Physical Education of the Philippine Normal University is the primary source of high quality teachers equipped with knowledge and pedagogical skills inclusive of the physical and health aspects of the discipline for the holistic development of individual learners. Its curriculum provides Physical Education teachers with the necessary body of knowledge, skills, positive attitudes and values, and special trainings in achieving high quality education in teacher education. Further, it develops academically independent, globally competitive and empowered Physical Education teachers imbued with human values, academic competence and integrity, professionalism, and responsibility.

The department's current curricular program was approved in April, 2006 and implemented in June of the same year.

This study was undertaken to provide data for the review and evaluation of the curricular program of the Department of Physical Education by conducting a tracer study of the Program's graduates. It partly reviewed the implementation of the existing curriculum and has gathered feedback from Physical Education major graduates. The data is expected to aid the Department in determining if the goals and objectives resulting from the implementation of the curricular program were met.

1. Establish the profile of the PNU PE major graduates in terms of:

\subsection{Employment Characteristics \\ 1.2 Transition to Employment}

2. Assess the PE major graduates' level of satisfaction with the University's services, learning environment and facilities

3. Determine the extent of the curricular program's contribution in the development of the graduates in terms of:

3.1 communication skills

3.2 human relations skills

3.3 leadership skills

3.4 problem solving skills

3.5 research skills

4. Assess the degree of adequacy and relevance of the Physical Education Program; and

5. Determine the graduates' perception of their academic experiences in the University.

Several studies on tracer study were conducted and discussed here to provide background of the study. The Philippine Normal University Accelerated Teacher Education Model (ATEM-PLUS) provides an alternative pre-service Teacher Education program. As mentioned in the first evaluation of the ATEM-PLUS (Mancao and 
Balagtas, 2008), one of the concerns in offering this curricular program which entailed more than a million pesos for scholarship and stipend, notwithstanding the experience of a hectic, harassed school life, was to make certain that ATEM-PLUS graduates get employed as elementary teachers as envisioned.

The tracer study conducted by Mancao (2010) provides data that assuage the academic community that the ATEM-PLUS program has been worth the resources extended to bring to fruition its goals and mission. Several factors are praiseworthy: that the graduates passed and most of them were in the top ten in the Licensure Examination for Teachers (LET); that they are in the teaching profession; that majority of them are in fulltime, permanent status; and that they are satisfied with their first job.

Given these results, the ATEM-PLUS program can unquestionably be offered as an official alternative BEED degree, subject to the consideration and implementation of the various recommendations already stated in several ATEM-PLUS monitoring reports.

Another study, that of Dumas and Dumlao (2011) conducted a Graduate Tracer Study of the Bachelor of Elementary Education in Bataan Peninsula State University (BPSU), and it aimed to magnify the current employment status of the BEEd graduates from the school year 2004 - 2009. Specifically, it sought to unveil the employment data of the respondents as to regular/permanent, casual, contractual, self-employed, unemployed, and abroad. It also assessed the viability of the present BEED Program of the BPSU College of Education as to catering the demands of the community and the neighboring provinces.

The study made use of the descriptive survey method which actually involved two faculty researchers and the thirty percent of the actual 403 graduates which comprised 120 respondents from SY 2004 - 2009. The main instrument used for gathering data was a questionnaire- checklist based on CHED Graduate Tracer Study Format.

The significant findings of this study were as follows: a) Most of the respondents came from the province of Bataan and most were female respondents; b) There were only 51 respondents who were LET eligible and only 2 were CSE qualified; c) There were only 5 holders of MAEd and none among the respondents were holders of $\mathrm{Ph}$. D. /Ed/D. degrees as their highest educational attainment; d) As to employment status, 32 were regular/permanent, 19 were contractual; e) The curriculum relevance according to the respondents was 75 and 
those who answered NO did not give any suggestions to further improve the curriculum; f) Among the competencies measured, communication skills ranked 1 st, human relations ranked 2 nd while entrepreneurial skills ranked $6^{\text {th }}$; g) It was significant to note that among the 120 respondents, 52 were self-employed.

The study of Sarabia (2012) gave the following conclusions: (1) the personal information and educational background of the respondents, manifested a direct bearing on the graduates' perception on school profile; (2) the graduates' perception on school profile was shown to have greatly influenced the graduates' perception of the subject areas to undergraduate curriculum, licensure examination and professional practice; (3) the graduates perception on the relevance of the subject areas to licensure examination and employment point to a need for a more enhanced curriculum that explores varied Social Studies content and applications; (4) the graduates perceived their teaching competence as satisfactory based on the quality of BSED Social Studies curriculum; (5) the status of the respondents' employability are strong determinants of the graduates' perceptions on the effectiveness of BSED Social Studies curriculum; (6) suggestions and recommendations proposed by the respondents to enhance the curriculum must be considered to respond to the weaknesses mentioned in the findings.

He further added the following recommendations: (1) inclusion of subjects in the curriculum that will develop the students' communication, human relations, and critical thinking skills; (2) revision of the facilitation methodology in teaching the subjects to a more practical, hands-on training approach; (3) acquisition of more modern information, communication, and technology facilities and equipment by the school; (4) use of tracer study as a marketing tool as well as an evaluation tool to bring about the fit between the requirements of the employment world and study; and (5) conduct of similar tracer studies involving other programs offered by BulSu as a marketing strategy to recruit new students.

\section{METHOD}

The research used the descriptive design. It was, in part, a curriculum product evaluation that documented curriculum relevance and adequacy in determining how well the products (the graduates) have achieved the goals of the curricular program. The study was designed to obtain both quantitative and qualitative data from the graduates of the program. Respondents of the study consisted of random samples from the three batches of the P.E. Curricular Program from 2009 - 2011.This research used the following data-gathering tools/procedure: 
1.) Questionnaire developed by CHED, specifically for Tracer Study research. These were used to obtain quantitative and qualitative feedback from the graduates about their course-related skills, attitudes, reactions and suggestions. The rating scale intended to determine the adequacy and relevance of the different course competencies of the program. The scale items consisted of program competencies resulting from the review of the course syllabi. The Tracer Survey Questionnaire was made available to the respondents through the web; 2.) Focus Group Discussions. FGDs were conducted to selected graduates to gather their collective experiences and feedback about the strengths and weaknesses of the courses taken and their recommended changes which would improve the courses and their delivery. A set of Guide Questions was prepared for this purpose.

The researcher tracked down and set up a directory of the graduates covered by the study. As soon as they were located, they were asked to accomplish the web-based questionnaire. Means were computed to analyze quantitative data. Qualitative data were coded and clustered thematically.

\section{RESULTS AND DISCUSSION}

1. Profile of the Philippine Normal University (PNU) Physical Education (PE) major graduates in terms of employment characteristics and transition to employment

Table 1. Frequency and Percentage Distribution of Respondents

\begin{tabular}{|c|c|c|}
\hline Gender & $\begin{array}{c}\text { Frequency } \\
\text { (f) }\end{array}$ & Percentage (\%) \\
\hline Male & 24 & 50 \\
\hline
\end{tabular}

\begin{tabular}{|c|c|c|}
\hline Female & 24 & 50 \\
\hline Total & 48 & 100 \\
\hline
\end{tabular}

Of the 48 PNU PE major graduates who participated in the study, $24(50 \%)$ are males and $24(50 \%)$ are females. This shows that there is an equal number of male and female respondents in the study as shown in Table 1. 
'Table 2. Frequency and Percentage Distribution of Respondents according to Age

\begin{tabular}{|c|c|c|}
\hline \multicolumn{3}{|c|}{$\mathrm{N}=48$} \\
\hline Age & Frequency & Percentage \\
\hline 21 & 4 & 8.33 \\
\hline 22 & 13 & $2 \% .08$ \\
\hline 23 & 6 & 12.50 \\
\hline 24 & 14 & $29.1 \%$ \\
\hline 25 & 4 & 8.33 \\
\hline 26 & 4 & 8.33 \\
\hline 27 & 1 & 2.08 \\
\hline 28 & 0 & 0 \\
\hline 29 & 1 & 2.08 \\
\hline 30 & 1 & 2.08 \\
\hline Total & 48 & 100 \\
\hline
\end{tabular}

As shown in Table 2, most of the respondents are of age 24 (14 respondents), 22 (13 respondents), 23 (6 respondents) and the rest are almost evenly distributed in age 21, 25, 26 (4 respondents per age) and 27, 29 and 30 ( 1 respondent per age). 'lable 3. Reasons for Enrolling in PNU

\begin{tabular}{|c|c|c|c|}
\hline Reasons* & Frequenc & Percentag & Rank \\
\hline Attordable luition Fee & 35 & T2.92 & 1 \\
\hline Personal Prestige of being at PNU & 32 & 66.67 & 2 \\
\hline Prospect for Better Employment & 25 & 52.08 & 3 \\
\hline Prospect for Career Advancement & 21 & 43.75 & 4 \\
\hline Availability of Scholarship & 17 & 35.42 & 5 \\
\hline School Location & 15 & 31.25 & 6 \\
\hline Fultillment ot dream to study at & 14 & $29.1 /$ & $/$ \\
\hline Otherll' & 2 & 4.17 & 8 \\
\hline
\end{tabular}

As regards the reasons of graduates for enrolling in PNU as shown in Table 3, Affordable Tuition Fee ranked first, followed by Personal Prestige of being at PNU, Prospect for Better Employment, Prospect for Career Advancement, Availability of Scholarship, School Location and Fulfillment of Dream to Study at PNU.

I'able 4. Enrollment in Other Courses

\begin{tabular}{|c|c|c|}
\hline Responses & Frequency & Percentage \\
\hline Yes, enrolled & 2 & 4.17 \\
\hline No, did not enroll & 46 & 95.83 \\
\hline Total & 48 & 100 \\
\hline
\end{tabular}

As shown in Table 4, forty-six (95.83\%) of the respondents were not enrolled in other courses. Only 2 (4.17\%) respondents enrolled in the other courses. 
Table 5. Frequency and Percentage Distribution of Respondents according to Current Employment Status

\begin{tabular}{|c|c|c|}
\hline Responses & Frequency & Percentage \\
\hline Employed & 44 & 91.67 \\
\hline Not employed & 4 & 8.33 \\
\hline Total & 48 & 100 \\
\hline
\end{tabular}

Table 5 shows that majority of the respondents $(91.67 \%)$ were employed. Only $4(8.33 \%)$ were not employed. This implies that most of the graduates of the program were employed.

'rable 6. Frequency and Percentage Distribution of Respondents Employment Status according to

\begin{tabular}{|c|c|c|}
\hline Employment Status & Frequency & Percentage \\
\hline Fulltime & 44 & y1.6/ \\
\hline Part-time & 0 & 0 \\
\hline Selt-employed & 4 & 8.33 \\
\hline Total & 48 & 100 \\
\hline
\end{tabular}

Table 6 shows that 91.67 percent (44) of the respondents were already employed on fulltime basis and only 8.33 percent (4) were self- employed. No one among the respondents was employed on a part time basis.

Table 7. Extent of Use of Skills in Current Employment

\begin{tabular}{|c|c|c|c|c|c|c|c|c|c|c|}
\hline \multirow[t]{2}{*}{ SKILLS } & \multicolumn{2}{|c|}{$\begin{array}{c}\text { To A } \\
\text { Great } \\
\text { Extent }\end{array}$} & \multicolumn{2}{|c|}{$\begin{array}{c}\text { To Some } \\
\text { Extent }\end{array}$} & \multicolumn{2}{|c|}{ Limited } & \multicolumn{2}{|c|}{$\begin{array}{l}\text { Very } \\
\text { Limite } \\
\text { d }\end{array}$} & \multicolumn{2}{|c|}{$\begin{array}{l}\text { Not at } \\
\text { All }\end{array}$} \\
\hline & $\mathrm{t}$ & $\%$ & $t$ & $\%$ & $\mathrm{t}$ & $\%$ & $\mathrm{t}$ & $\%$ & $\mathrm{t}$ & $\%$ \\
\hline $\begin{array}{l}\text { Knowledge } \\
\text { and }\end{array}$ & 32 & 66.61 & 13 & 21.08 & 3 & 6.25 & 0 & 0 & 0 & 0 \\
\hline $\begin{array}{l}\text { Communicati } \\
\text { on }\end{array}$ & 25 & 52.08 & 21 & 43.15 & 2 & 4.17 & 0 & 0 & 0 & 0 \\
\hline $\begin{array}{l}\text { Human } \\
\begin{array}{l}\text { Helations } \\
\text { Skills }\end{array} \\
\end{array}$ & 33 & $68 . / 5$ & 13 & $2 \% .08$ & 2 & 4.11 & 0 & 0 & 0 & 0 \\
\hline
\end{tabular}




\begin{tabular}{|c|c|c|c|c|c|c|c|c|c|c|}
\hline $\begin{array}{c}\text { Leadership } \\
\text { Skills }\end{array}$ & 29 & 60.42 & 16 & 33.33 & 3 & 6.25 & 0 & 0 & 0 & 0 \\
\hline $\begin{array}{l}\text { Research } \\
\text { Skills }\end{array}$ & 18 & $3 / .50$ & $1 /$ & 35.42 & 1 & 25 & 0 & 0 & 1 & 2.08 \\
\hline $\begin{array}{c}\text { Problem } \\
\text { Solving }\end{array}$ & 21 & 43.15 & 22 & 45.83 & 3 & 6.25 & 1 & 2.08 & 1 & 2.08 \\
\hline $\begin{array}{c}\text { Intormat10 } \\
\text { n } \\
\text { Technology } \\
\text { c1:illog }\end{array}$ & 16 & 33.33 & 22 & 45.83 & 8 & $7^{6.6}$ & 2 & $4.1 /$ & 0 & 0 \\
\hline
\end{tabular}

As shown in Table 7, Knowledge and Technical Skills, Communication Skills, Human Relations Skills, Leadership Skills and Research Skills were all used to a great extent while Problem Solving Skills and Information Technology Skills were only used by the respondents to some extent. The data indicate that all skills gained from their education were used in their current employment.

\begin{tabular}{|c|c|c|c|c|}
\hline \multirow{2}{*}{ SKILLS } & \multicolumn{2}{|c|}{ Provided } & \multicolumn{2}{|c|}{ Not provided } \\
\hline & $\mathrm{t}$ & $\%$ & $\mathrm{t}$ & $\%$ \\
\hline Knowledge and Technical & 47 & 97.92 & 1 & 2.08 \\
\hline Communication Skills & 41 & प्रा.92 & 1 & 2.08 \\
\hline Human Relations Sk1lls & 40 & प्र.83 & $\frac{1}{2}$ & 4.11 \\
\hline Leadership Skills & 48 & 100 & 0 & 0 \\
\hline Research Skills & 44 & प्र1.61 & 4 & 8.33 \\
\hline Problem-solving Sk1lls & 44 & 91.61 & 4 & 8.33 \\
\hline Intormation Technology Skills & 44 & 91.61 & 4 & 8.33 \\
\hline
\end{tabular}

Table 8 shows that the skills the respondents use in their employment were all provided in their pre-service training. Among these skills, leadership skills got the highest percentage (100\%).

Table 9. Use of Skills/Qualifications in Current Employment which are not related to Undergraduate Degree

\begin{tabular}{|c|c|c|}
\hline Responses & Frequency & Percentage \\
\hline Yes & 6 & 12.5 \\
\hline No & 42 & $8 / .5$ \\
\hline Total & 48 & 100 \\
\hline
\end{tabular}

As shown in Table 9, most of the respondents, 42, (87.5\%) did not use any other skills / qualifications in their present job which are not related to their undergraduate degree. Only $6(12.5 \%)$ among the respondents used other skills / qualifications in their current employment which are not related to their undergraduate degree. 
Table 10. Degree of Relation of Training Received in the

Undergraduate Program to Tasks Performed in Current Employment

\begin{tabular}{|c|c|c|}
\hline Responses & Frequenc & Percentage \\
\hline Very Much & 37 & 77.08 \\
\hline Much & 7 & 14.58 \\
\hline Slightly & 4 & 8.33 \\
\hline Not related at all & 0 & 0 \\
\hline Total & 48 & 100 \\
\hline
\end{tabular}

As revealed in Table 10, majority of the respondents (37) were able to relate "Very Much" to the training received in their Undergraduate Program to the performance of the tasks in their current employment. Seven (7) were able to relate "Much" and only 4 were able to relate "Slightly" to the training received in the Undergraduate Program to the performance of the tasks $n$ their current employment.

Table 11. Length of Time in Acquiring First Job

\begin{tabular}{|c|c|c|}
\hline Responses & Frequency & Percentage \\
\hline Right after graduation & 38 & 79.17 \\
\hline Less than a year & 8 & 16.67 \\
\hline More than a year & 1 & 2.08 \\
\hline Others & 1 & 2.08 \\
\hline Total & 48 & 100 \\
\hline
\end{tabular}

As shown in Table 11, out of the 48 graduates who participated in the study, $38(79.17 \%)$ acquired their first job right after graduation; $8(16.67 \%)$ of the respondents, "Less than a year," 1 $(2.08 \%)$ "More than a year" and $1(2.08 \%)$ did not specify any data in the length of time in acquiring his/her first job.

lable I'2. Conditions in Acquiring First Job

\begin{tabular}{|c|c|c|}
\hline Responses & Frequenc & Percentage \\
\hline By Application & 40 & 83.33 \\
\hline Political Connection & 1 & 2.08 \\
\hline By Invitation & 5 & 10.42 \\
\hline Uthers & 2 & $4.1 /$ \\
\hline Total & 48 & 100 \\
\hline
\end{tabular}

As regards the conditions of graduates in acquiring their first job, Table 12 shows that $83.33 \%$ (40) is By Application, $10.42 \%$ (5) is By

Invitation, $2.08 \%$ (1) is through Political Connection and 4.17 (2) is by Other Conditions, which are not stated. 
Iable 13. Difficulties Encountered in Looking for a Job

\begin{tabular}{c|c|c|c}
\hline Difficulties* & Frequency & Percentage & Rank \\
$\begin{array}{c}\text { Few job vacancies / lack of position } \\
\text { or item }\end{array}$ & 19 & 39.58 & 1 \\
\hline $\begin{array}{c}\text { Inadequate experience } \\
\text { Uthers* }\end{array}$ & 12 & 25 & 2.5 \\
\hline $\begin{array}{c}\text { Passing the pre-employment exam } \\
\text { Personality factors }\end{array}$ & 6 & 12.50 & 4 \\
\hline $\begin{array}{c}\text { Not meeting paper requirement/s } \\
\text { Mismatch of educational } \\
\text { qualifications }\end{array}$ & 5 & 10.42 & 5.5 \\
\hline $\begin{array}{c}\text { Lack of political patronage } \\
\text { interview }\end{array}$ & 3 & 6.25 & 7.5 \\
\hline Passing the pre-employment & 2 & 6.25 & 7.5 \\
\hline Inadequate knowledge or sk1lls & 2 & 4.17 & 9.5 \\
\hline
\end{tabular}

Table 13 presents the difficulties that the respondents experienced in applying for their job. Those that rank high are Few job vacancies / lack of position or item (rank 1), inadequate experience (2.5) and the other; (2.5) passing the pre-employment exam, Personality factors (5.5), not meeting paper requirement/s (5.5), mismatch of educational qualifications (7.5) and lack of political patronage (7.5) and Passing the preemployment interview (9.5) and inadequate knowledge or skills (9.5) shared the last rank.

Iable 14. Factors Facilitating Acquisition of First Job

\begin{tabular}{|c|c|c|c|}
\hline Reasons* & Frequen & Percentage & Rank \\
\hline Area of Specification & 43 & 89.58 & 1 \\
\hline Reputation ot the College / & 35 & 72.92 & 2 \\
\hline Personality factors & 34 & 70.83 & 3 \\
\hline Scholastic standing & 16 & 33.33 & 4 \\
\hline Uthers** & 1 & 2.08 & 5 \\
\hline
\end{tabular}

The data in Table 14 revealed the Factors/Reasons why they were hired on their first job. Area of specialization was the very first reason (rank 1); followed by the reputation of the college / university (rank 2); Personality factors (rank 3); and Scholastic standing,.

I'able 15. Relation of First Job to Area of Specialization

\begin{tabular}{|c|c|c|}
\hline Responses & Frequency & Percentage \\
\hline Related & 46 & Y5.83 \\
\hline Not related & 2 & $4.1 /$ \\
\hline Iotal & 48 & 100 \\
\hline
\end{tabular}


Table 15 shows that of the 48 respondents, 46 (95.83\%) perceived that their area of specialization was very much related to their first job while $2(4.17 \%)$ considered that their area of specialization was not related to their first job.

1. The PE major graduates' level of satisfaction with the university's services, learning environment and facilities

lable 16. Degree of Satisfaction with Services Provided in PNU

\begin{tabular}{c|r|c}
\hline Services & Mea & Interpretation \\
\hline Administrative Support & 3.77 & High Satisfaction \\
\hline Faculty Support & 4.27 & High Satisfaction \\
\hline Staff & 3.73 & High Satisfaction \\
\hline Academic Advising & 4.04 & High Satisfaction \\
\hline Guidance and Counseling & 3.56 & High Satisfaction \\
\hline Accommodation & 3.88 & High Satisfaction \\
\hline Food Services & 3.52 & High Satisfaction \\
\hline Library Services & 4.08 & High Satisfaction \\
\hline Extension/Uutreach/Community & 4.19 & High Satisfaction \\
\hline Inulvement & Very H1gh \\
\hline Extra-curricular activities & 4.56 & Saticactann \\
\hline Co-curricular activities & 4.46 & High Satisfaction \\
\hline Security & 4.02 & High Satisfaction \\
\hline & &
\end{tabular}

As regards the degree of Satisfaction with the services provided in PNU as shown in Table 16, the respondents indicated a very high satisfaction (4.56) with the extra-curricular activities. They indicated high satisfied with the co-curricular activities (4.46); Faculty Support (4.27); Extension/Outreach/Community Involvement (4.19); Library Services (4.08); Academic Advising (4.04); Security (4.02); Accommodation (3.88); Administrative Support (3.77); Staff (3.73); Guidance and Counseling'(3.56); and Food Services (3.52).

Table 17. Degree of Satisfaction with the Learning Environment /

\begin{tabular}{l|c|c}
\multicolumn{2}{c}{ Climate in PNU } \\
\hline \multicolumn{1}{c}{ Learning Environment/Climate } & Mean & Interpretation \\
\hline Teaching Staff & & \\
\hline Knowledge of content & 4.38 & High Satisfaction \\
\hline Interaction with students & 4.27 & High Satisfaction \\
\hline Creativity in teaching & 4.19 & High Satisfaction \\
\hline Delivery Skills / Teaching Methods & 4.33 & High Satisfaction \\
\hline 'Instructional Materials & 3.94 & High Satisfaction \\
\hline 'Respect for Students & 4.10 & High Satisfaction \\
\hline $\begin{array}{l}\text { Atmosphere of political and cultural } \\
\text { Inderstanding }\end{array}$ & 3.98 & High Satisfaction \\
\hline
\end{tabular}

It can be noted in Table 17 that they indicated high 
satisfaction with the learning environment, particularly in the knowledge of content, Delivery Skills / Teaching Methods, interaction with students, and creativity in teaching of the Faculty of Physical Education Department (mean $=4.38 ; 4.33 ; 4.27 ; 4.19$ respectively).

Table 18. Degree of Satisfaction with the Facilities in

\begin{tabular}{c|r|l} 
FNU & \multicolumn{3}{|c}{$\mid$ Mean $\mid$ Interpretation $\mid$} \\
\hline Library & 4.13 & High \\
\hline Science Laboratories & 3.69 & High \\
\hline Computer Laboratories & 3.63 & High \\
\hline Equipment & 3.60 & High \\
\hline Classroom & 3.69 & High \\
\hline Clinic & 3.90 & High \\
\hline Canteen / Food Stalls & 3.56 & High \\
\hline Recreational Facilities & 3.90 & High \\
\hline Audio-Visual Room & 3.96 & High \\
\hline Auditorium & 3.85 & High \\
\hline Communication Facilities & 3.66 & High \\
\hline General conditions of Building and Grounds & 3.73 & High
\end{tabular}

The data presented in Table 18 reveal the respondents' high satisfaction with the facilities in PNU, particularly with the library which got the highest weighted mean (4.13); followed by the audiovisual room with a weighted mean of 3.96 ; then the clinic and recreational facilities got the same weighted means of 3.90. Next, the auditorium and the general conditions of building and grounds with weighted means of 3.85 and 3.73 respectively. Science Laboratories and Classroom also got the same weighted means of 3.69, followed by the communication Facilities, Computer Laboratories, Equipment and Canteen / Food Stalls which had the lowest weighted means of all the facilities rated $3.66 ; 3.63 ; 3.60 ; 3.56$ respectively.

2. Extent to which the curricular program contributed to the development of the graduates' skills 
Table 19. Adequacy of Training on Communication Skill

\begin{tabular}{|l|l|l|}
\hline \multicolumn{1}{|c|}{ Communication Skills } & Mean & Interpretation \\
\hline \begin{tabular}{l} 
1. Express ideas in clear and logical manner \\
\hline $\begin{array}{l}\text { 2. Use various forms and styles of written } \\
\text { communication }\end{array}$
\end{tabular} & 4.04 & $\begin{array}{l}\text { Very } \\
\text { Adequate }\end{array}$ \\
\hline $\begin{array}{l}\text { 3. Use grammatically correct language and } \\
\text { vocabularv }\end{array}$ & 3.96 & $\begin{array}{l}\text { Very } \\
\text { Adequate }\end{array}$ \\
\hline $\begin{array}{l}\text { 4. Listen with objectivity to gain understanding } \\
\text { of the ideas of Others }\end{array}$ & 4.04 & $\begin{array}{l}\text { Very } \\
\text { Adequate }\end{array}$ \\
\hline Overall Mean & $\begin{array}{l}\text { Very } \\
\text { Adequate }\end{array}$ \\
\hline
\end{tabular}

Table 20. Adequacy of Training on Human Relation Skills in PNU

\begin{tabular}{l|l|l}
\hline \multicolumn{1}{c|}{ Human Relations Skills } & Mean & Interpretation \\
\hline $\begin{array}{l}\text { 1. Demonstrate effective social behavior in a } \\
\text { variety of setting and under different }\end{array}$ & 4.23 & $\begin{array}{l}\text { Very } \\
\text { Adequate }\end{array}$ \\
\hline $\begin{array}{l}\text { 2. Respond to the needs of colleagues in the } \\
\text { 3. Apply effective conflict resolution skills }\end{array}$ & 4.23 & Very \\
\hline $\begin{array}{l}\text { 4. Foster professional relationships with people } \\
\text { in the Workplace }\end{array}$ & 4.29 & Very \\
\hline
\end{tabular}

\begin{tabular}{l|l|l}
\hline $\begin{array}{l}\text { 5. Exhibit cooperative and supportive relations } \\
\text { with others }\end{array}$ & 4.35 & $\begin{array}{l}\text { Very } \\
\text { Adequate }\end{array}$ \\
\hline & 4.26 & $\begin{array}{l}\text { Very } \\
\text { Adequate }\end{array}$ \\
\hline
\end{tabular}


Table 21. Adequacy of Training on Leadership Skills in PNU

\begin{tabular}{l|l|l}
\hline \multicolumn{1}{c|}{ Leadership Skills } & Mean & Interpretati \\
\hline $\begin{array}{l}\text { 1. Stimulate collaborative efforts with } \\
\text { colleagues in the Workplace }\end{array}$ & 4.25 & $\begin{array}{l}\text { Very } \\
\text { Adequate }\end{array}$ \\
$\begin{array}{l}\text { 2. Motivate, mobilize and inspire people to } \\
\text { move toward the goal of the organizations }\end{array}$ & 4.31 & $\begin{array}{l}\text { Very } \\
\text { Adequate }\end{array}$ \\
$\begin{array}{l}\text { 3. Organize and coordinate people and tasks to } \\
\text { achieve the organization's goal }\end{array}$ & 4.21 & $\begin{array}{l}\text { Very } \\
\text { Adequate }\end{array}$ \\
$\begin{array}{l}\text { 4. Facilitate effective implementation of } \\
\text { programs of the }\end{array}$ & 4.25 & $\begin{array}{l}\text { Very } \\
\text { Adequate }\end{array}$ \\
\hline $\begin{array}{l}\text { 5. Maintain self-control in the midst of stressful } \\
\text { encounters with group members }\end{array}$ & 4.21 & $\begin{array}{l}\text { Very } \\
\text { Adequate }\end{array}$ \\
\hline $\begin{array}{c}\text { 6. Take responsibility and risks in making } \\
\text { Overall Mean }\end{array}$ & 4.33 & Very \\
\hline
\end{tabular}

Table 22. Adequacy of Training on Problem Solving Skills in PNU

\begin{tabular}{|l|l|l|}
\hline \multicolumn{1}{|c|}{ Problem Solving Skills } & Mean & \multicolumn{1}{|c|}{ Interpretati } \\
\hline $\begin{array}{c}\text { 1. Identify the underlying issues in a problem } \\
\begin{array}{c}\text { 2. Examine alternative solutions and strategies } \\
\text { to make an informed decision on the }\end{array}\end{array}$ & 4.17 & Very \\
\hline $\begin{array}{c}\text { 3. Develop a clear plan to solve the problem } \\
\text { 4. Evaluate action for making future decision }\end{array}$ & 4.23 & $\begin{array}{l}\text { Very } \\
\text { Adequate }\end{array}$ \\
\hline Overall Mean & 4.21 & Very \\
\hline
\end{tabular}

Table 23. Adequacy of Training on Research Skills in PNU

\begin{tabular}{|c|c|c|}
\hline Research Skills & Mean & Interpretati \\
\hline 1. Identify research problems in one's discipline & 4.04 & Very \\
\hline 2. Formulate testable hypothesis & 4.04 & Very \\
\hline $\begin{array}{l}\text { 3. Demonstrate knowledge of various data } \\
\text { gathering Techniques }\end{array}$ & 4.17 & $\begin{array}{l}\text { Very } \\
\text { Adequate }\end{array}$ \\
\hline 4. Apply appropriate statistics in processing & 4.13 & Very \\
\hline 5. Analyze and interprets research results & 4.10 & Very \\
\hline 6. Draw conclusions and generalization from & 4.13 & Very \\
\hline 7. Use technology to acquire needed & 4.13 & Very \\
\hline Overall Mean & 4.11 & Very \\
\hline
\end{tabular}

For the adequacy of training they received with regard to the number of identified skills, they rated the adequacy of skills learned on a scale of 1 to 5 , where 1 is not adequate and 5 is extremely adequate. The respondents indicated that they have "Very Adequate" training on Communication Skills (Table 19); Human Relations Skills 
(Table 20); Leadership Skills (Table 21); Problem Solving Skills (Table 22); and Research Skills (Table 23) as shown by the overall mean of $4.04 ; 4.26 ; 4.26 ; 4.21$; and 4.11 respectively. The content of the said skills gave them knowledge to navigate the world of work.

3. Degree of adequacy and relevance of the Physical Education Program

Table 24. Adequacy and Relevance of Pre-Service Training in Relation to Curricular Program Competencies

\begin{tabular}{|c|c|c|c|c|}
\hline \multirow[b]{2}{*}{ Competencies } & \multicolumn{2}{|c|}{ Adequacy } & \multicolumn{2}{|r|}{ Relevance } \\
\hline & Mean & Interpretation & Mean & Interpretation \\
\hline $\begin{array}{l}\text { Expresses ideas, } \\
\text { eelings, emotion, and } \\
\text { noods through rhythmic } \\
\text { ctivities, dance, sports } \\
\text { nd recreation activities; }\end{array}$ & 4.54 & $\begin{array}{l}\text { Extremely } \\
\text { Adequate }\end{array}$ & 4.69 & $\begin{array}{l}\text { Extremely } \\
\text { Relevant }\end{array}$ \\
\hline $\begin{array}{l}\text {.. Utilizes teaching } \\
\text { pproaches and } \\
\text { nethodologies } \\
\text { ppropriate to the } \\
\text { eaching of health, dance, } \\
\text { ports, and recreational } \\
\text { ctivities and learning } \\
\text { tyles of the students; }\end{array}$ & 4.48 & $\begin{array}{c}\text { Very } \\
\text { Adequate }\end{array}$ & 4.52 & $\begin{array}{l}\text { Extremely } \\
\text { Relevant }\end{array}$ \\
\hline $\begin{array}{l}\text { Possesses adequate } \\
\text { 'ody of knowledge on } \\
\text { he concept of } \\
\text { novements, musical } \\
\text { hythm, and dance; }\end{array}$ & 4.56 & $\begin{array}{l}\text { Extremely } \\
\text { Adequate }\end{array}$ & 4.67 & $\begin{array}{l}\text { Extremely } \\
\text { Relevant }\end{array}$ \\
\hline $\begin{array}{l}\text { Analyzes biochemical } \\
\text { novements of different } \\
\text { ames, sports, and dance } \\
\text { kills; }\end{array}$ & 4.33 & $\begin{array}{c}\text { Very } \\
\text { Adequate }\end{array}$ & 4.61 & $\begin{array}{l}\text { Extremely } \\
\text { Relevant }\end{array}$ \\
\hline $\begin{array}{l}\text { Respects and } \\
\text { cknowledges judgments } \\
\text { if persons in authority in } \\
\text { he conduct of dance, } \\
\text { ports competition as a } \\
\text { oach, trainor, or player. } \\
\text { t true Physical Educator } \\
\text { hows sportsmanship in } \\
\text { vinning or losing a } \\
\text { ames and other } \\
\text { ompetitions; }\end{array}$ & 4.12 & $\begin{array}{l}\text { Extremely } \\
\text { Adequate }\end{array}$ & 4.12 & $\begin{array}{l}\text { Extremely } \\
\text { Relevant }\end{array}$ \\
\hline $\begin{array}{l}\text { Conducts systematic } \\
\text { nquiry aimed at } \\
\text { roviding information to } \\
\text { olve problems, discover } \\
\text { ew body of knowledge } \\
\text { nd developing new } \\
\text { irograms in health and } \\
\text { hysical education; }\end{array}$ & 4.41 & $\begin{array}{c}\text { Very } \\
\text { Adequate }\end{array}$ & 4.43 & $\begin{array}{l}\text { Very } \\
\text { Relevant }\end{array}$ \\
\hline
\end{tabular}




\begin{tabular}{|c|c|c|c|c|}
\hline $\begin{array}{l}\text { 7. Advocates cultural } \\
\text { activities showing } \\
\text { Filipino cultural heritage; }\end{array}$ & 4.55 & $\begin{array}{l}\text { Extremely } \\
\text { Adequate }\end{array}$ & 4.67 & $\begin{array}{l}\text { Extremel } \\
\text { y } \\
\text { Relevant }\end{array}$ \\
\hline $\begin{array}{l}\text { 8. Advocates the inclusion } \\
\text { of indigenous sports and } \\
\text { games, dances and } \\
\text { equipment in the physical } \\
\text { education curriculum; }\end{array}$ & 4.46 & $\begin{array}{c}\text { Very } \\
\text { Adequate }\end{array}$ & 4.71 & $\begin{array}{l}\text { Extremel } \\
\text { y } \\
\text { Relevant }\end{array}$ \\
\hline $\begin{array}{l}\text { 9. Extends services to the } \\
\text { community for fitness } \\
\text { literacy through proper } \\
\text { conduct of sports, games, } \\
\text { and recreational activities; }\end{array}$ & 4.54 & $\begin{array}{l}\text { Extremely } \\
\text { Adequate }\end{array}$ & 4.56 & $\begin{array}{l}\text { Extremel } \\
\text { y } \\
\text { Relevant }\end{array}$ \\
\hline $\begin{array}{l}\text { 10. Regularly updates } \\
\text { knowledge on coaching } \\
\text { and officiating dance and } \\
\text { sports activities to make } \\
\text { sound judgments in the } \\
\text { performance of duty as a } \\
\text { coach / official judge in } \\
\text { any competition; }\end{array}$ & 4.23 & $\begin{array}{c}\text { Very } \\
\text { Adequate }\end{array}$ & 4.25 & $\begin{array}{l}\text { Very } \\
\text { Relevant }\end{array}$ \\
\hline $\begin{array}{l}\text { 11. Considers research } \\
\text { output / scientific findings } \\
\text { in sound decision making; }\end{array}$ & 4.27 & $\begin{array}{c}\text { Very } \\
\text { Adequate }\end{array}$ & 4.38 & $\begin{array}{l}\text { Very } \\
\text { Relevant }\end{array}$ \\
\hline $\begin{array}{l}\text { 12. Assumes self and } \\
\text { social responsibility in the } \\
\text { conduct of duty as a } \\
\text { professional. }\end{array}$ & 4.48 & $\begin{array}{c}\text { Very } \\
\text { Adequate }\end{array}$ & 4.60 & $\begin{array}{l}\text { Extremel } \\
\text { y } \\
\text { Relevant }\end{array}$ \\
\hline Overall Mean & 4.47 & $\begin{array}{c}\text { Very } \\
\text { Adequate }\end{array}$ & 4.57 & $\begin{array}{l}\text { Extremel } \\
\mathrm{y} \\
\text { Relevant }\end{array}$ \\
\hline
\end{tabular}

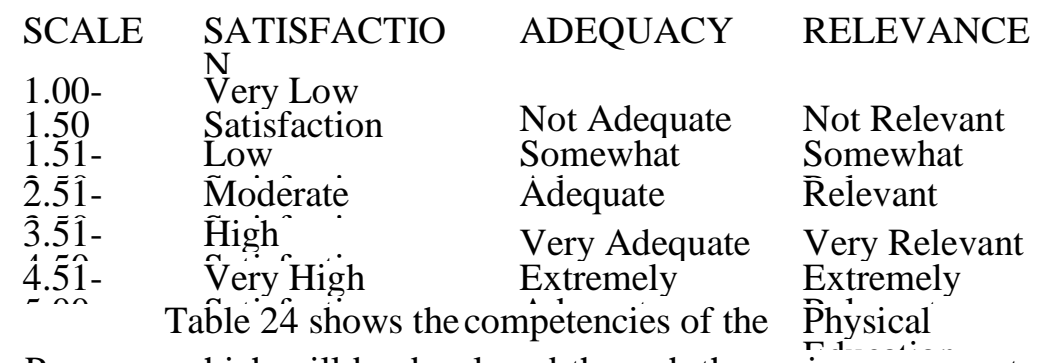

Program, which will be developed through the various courses to be taken by the students in their majorship / specialization courses. The graduates / respondents were asked to evaluate the set competencies of a Physical Education Teacher. A scale of 1 as very low satisfaction, not adequate, not relevant, and a scale of 5 as very high satisfaction, extremely adequate, and 
extremely relevant was used. Only the responses who were teaching PE, PEHM or MAPEH were considered.

As shown in Table 24, the respondents indicated a very adequate, with an overall mean of 4.47 , and extremely relevant with an overall mean of 4.57 , with the Pre-Service Training in relation to the Curricular Program Competencies.

4. The graduates' perception of their academic experiences in the university

As regards the graduates' perception of their academic experiences in PNU, "A set of Guide Questions for Focus Group Discussion" was used. And with reference to the three (3) components of the PNU curriculum, the responses were clustered according to the following components: General Education, Professional Education and Specialization.

Pertaining to the PNU curriculum, the following were some of the respondents' suggestions for the General Education Component:

1. Help PE majors improve their English Communication Skill

2. Assign Mathematics Professor who will teach the subject thoroughly, taking into consideration the weaknesses of the students

3. Improve the facilities and equipment

4. More computers for the "hands-on" of the students

Professional Education Component

5. Specialist / Expert fulltime Prof. Ed. Professors should handle Professional courses

6. Absolute supervision during the Off - Campus Practicum Specialization Component

7. Offer more units/subjects for Music and Arts which are necessary in teaching MAPEH

8. Give more "Rigid teaching and training for Coaching and Officiating

9. More exposure on Sports

\section{CONCLUSIONS}

In the light of the findings of the study, the following conclusions are hereby given: All skills learned and trainings received in the Undergraduate Program which were provided during Pre-Service Training, were used and very much related to the performance of the tasks in their current employment. Major proof of this is the fact that majority of the respondents were employed immediately after graduation; There was a high satisfaction with the University's services, learning environment and facilities. The respondents 
indicated a very high satisfaction with the extra curricular activities during their undergraduate studies; The curricular program provided a very adequate training on Communication Skills; Human Relations Skills; Leadership Skills; Problem Solving Skills; and Research Skills which led to the development of graduates; and The Physical Education Curricular Program is very adequate. The knowledge and skills developed during the Pre-service training are extremely relevant and useful to the Physical Education majors;

\section{REFERENCES}

Dumas, Dolores B. and Dumlao, Judy B. (2011). Graduate Tracer Study of the Bachelor of Elementary Education, SY 20042009. Bataan Peninsula State University, Bataan

Mancao, Ma. Carmela T. and Balagtas, Marilyn U. (2008). ATEMPLUS: An Evaluation. Philippine Normal University Center for Research and Development Research Series No. 99. May 2008

Mancao, Ma. Carmela T. (2010). A Tracer Study of the Graduates of ATEM- PLUS Part 1. Philippine Normal University Center for Research and Development Research Series No. 119. February 1-15, 2010

PNU National Center for Teacher Education (Republic Act No. 9647, July 28, 2008)

Sarabia, Julius V. (2012). Tracer Study of the Bachelor in Secondary Education Major in Social Studies Graduates of Bulacan State University. Unpublished Special Project, Philippine Normal University, Manila

Schomburg, Harald. (2003). Graduate Tracer Studies at the Kassel Centre. Centre for Research on Higher Education and Work, University of Kassel, Kasssel, Germany. Retrieved May, 2013fromwww.uni-

kassel.de/wz1/proj/edwork/mat/handbook_v2.doc 